\title{
Assessment and Evaluation of Volcanic Rocks Used as Construction Materials in the City of Addis Ababa
}

\author{
Tesfaye Asresahagne Engidasew ${ }^{1 *}$ and Asmelash Abay ${ }^{2}$ \\ ${ }^{1}$ Geomatrix PLC, P.O. Box. 534 code 1250, Addis Ababa, Ethiopia \\ (*tesfaye_asresahagne@yahoo.com). \\ ${ }^{2}$ Department of Earth Sciences, College of Natural and Computational Sciences, P.O. Box \\ 231, Mekelle University, Mekelle, Ethiopia.
}

\begin{abstract}
Addis Ababa capital city of Ethiopia at an elevation of about $2000 \mathrm{~m}$ above mean sea level is entirely covered with volcanic rocks, basalt, trachyte, ignimbrite and rhyolite. Construction industry makes use these rocks extensively and indiscriminately for structural loading, pavements, wall cladding, fencing, as cobblestone and masonry stones. The suitability of these rocks and their petrographic and physico-mechanical properties evaluation becomes important for their aforementioned applications. So, field observation and sample collection for laboratory investigations were conducted on six selected target areas of the city periphery. In doing so, the compressive strength, open porosity, water absorption and density of various volcanic rocks were studied in the central laboratory of the Geological Survey of Ethiopia. Based on the physico-mechanical test results, some layers of ignimbrites and rhyolites are found to be the best for use in the construction industry. Out of the six target areas, two areas located on the south and south eastern periphery of the Addis Ababa city were selected for possible dimension stone production. Therefore, these areas could be developed for dimension stone quarry and exploitation of these rocks could be as rough unprocessed building stone or better polished natural stones for a variety of uses.
\end{abstract}

Keywords: Volcanic rocks, Dimension stone, Physico-mechanical properties, Petrography, Addis Ababa, Ethiopia.

\section{INTRODUCTION}

The demand for geological construction materials is escalating from time to time due to the construction boom which is evidenced by unparallel expansion and upgradation of infrastructures such as highways, airports, schools, hospitals, public and private buildings in major towns, and particularly in Addis Ababa city. Among the construction activities, road construction by federal and regional governments, government financed housing projects (especially condominiums), and real estate projects are remarkable, and especially, the latter is contributing to solve critical housing problems in the capital and major towns of the country. These projects utilize voluminous geological construction materials, from quarries located in and around the city of Addis Ababa for using as building stone (cobblestone or pavements, structural loading, wall claddings, fencing etc.). To this end, the geology of Addis Ababa was reviewed, and geological assessment was conducted and several existing quarries were visited. During the assessment activities, areas with potential geological resources were 
selected and sampled. Some geological observation points were selected and geologically described in four main directions, North (Entoto-Sululta areas), South-South east (Bole Arabesa, Bole Lemi) and southwest (Hana Mariam) and East (Meri-Chefe-Sefera) of Addis Ababa city(Fig 1).

Owing to its varied and cyclic volcanic eruptions from main volcanic centres such as Yerer, Furi and others, the geology of the city of Addis Ababa is dominantly volcanic rocks comprised of both acidic and basic compositions such as tuff, rhyolite, ignimbrite, trachyte, and basalt. These rocks are important inputs for construction work in the city starting from the foundation of the city until today, and definitely will continue to be also in the future. From the assessment of various existing quarries and outcrops, the ignimbrite in different areas and rhyolite outcrop of northern Addis Ababa are mostly used as building stone. These rocks are generally porous, soft and easy to carve and split. Particularly, for a long time, ignimbrite and tuff are being used as building stones of Addis Ababa (Karstaedt and Wondafrash, 1986a and b).

Volcanic rocks have been widely used in various industrial applications in many parts of the world but the most widespread application is in the construction industry as crushed aggregate and building stone for various civil structures. Volcanic rocks are used extensively as engineering material throughout the world as aggregates in cement concrete, asphalt concrete, rock fill dams, railway ballast and high way base courses (Goodman, 1992). However, for each type of application, assessment of quality is required which depends on the property of the each rock type. Many authors addressed the issue of quality (Ramsay et al., 1974; Smith and Collis, 2001) in which rocks quality for construction material is governed by petrographic composition, texture, particle shape, porosity, among others. These properties directly affect the mechanical behavior of the rock in question. Further published laboratory test data on the property of volcanic rocks as building stone and aggregate indicate that volcanic rocks as construction material are very suitable for particular purpose (Tasong et al., 1998). On the other hand, volcanic rocks in general have diverse physic-mechanical properties than other rocks (Fookes, 1980; Neville, 1995).Thus, geological assessment, sampling, access and other relevant aspects were considered in the current evaluation of the resources. As the physical and mechanical tests determined the usability of the geological construction material, two sub-areas were selected essentially on the basis of the results of physico-mechanical tests, and petrographic studies of representative samples for dimension stone quarrying. 
Construction stone applies only to rock materials that are used directly for construction purposes that are, without calcining or chemical processing, for buildings, monuments, highways, aggregate, paving, retaining walls, sea walls and others. Shaped and finished blocks, slabs, rough quarry blocks, and crushed and broken stones are embraced in construction stones. Construction stone has a wide variety of uses, but it is convenient and practicable to classify it in two main categories, namely, crushed and broken stone and dimension stone. This study shall concentrate only on dimension stone (cobblestone, pavements, structural loading, cladding stone, floor tails, fencing, ceiling, corner stone etc.). Dimension stone is a collective term for various natural stones used for structural or decorative purposes in construction and monumental applications (Merke, 2000).

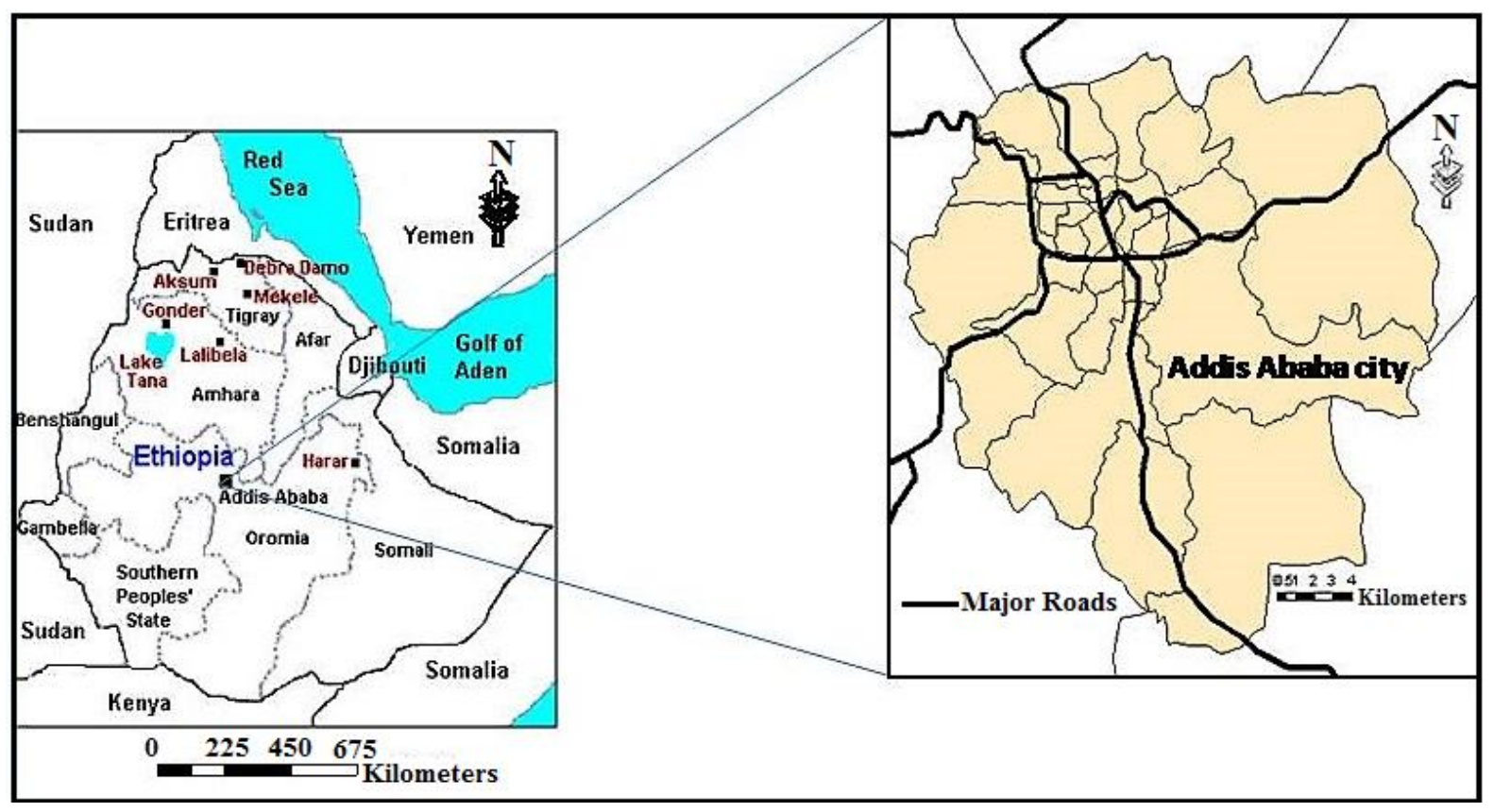

Figure 1. Location of the study area.

\section{METHODOLOGY}

The study on the geological construction materials involved desk study to select possible target areas at different parts of the city. A preliminary geological survey was carried out in different directions in order to rectify the plan for selecting areas of interest for study. This was followed by formal prospecting and selection of target areas using topographic maps. Targets were then studied and geological data were collected. The rock units were geologically described using conventional field techniques (description of texture, colour, extent of weathering and thickness of overburden etc) and measurements of geographic coordinate were taken using hand held GPS. Geological observations provided specific 
information on the nature of the rock units, depth, areal extent and usefulness as construction material deposit. Prospective deposits were identified and representative rock samples were collected from selected area for physico-mechanical tests and petrographic examination. Detailed geological mapping was conducted at selected sites in and around Addis Ababa to study and characterize geological construction materials used as dimension stones (Fig 2). The areas where the study was conducted include Bole Lemi, Hana Mariam and Chefe Sefera, Entoto, Bole Arabesa and Kality. Twenty four rock samples were collected from all sites for physico-mechanical tests and two samples for petrographic studies one each from Entoto and Hana Mariam sites because the rocks in these sites were fresh and less weathered (Fig 3).

Two rock samples were cut and thin sections prepared for petrographic examination at Addis Ababa. The rock sample from Hana Mariam area shows attractive faint green, and yellowish gray variety whereas the sample from Entoto ridge (forming an extensive outcrop) shows appealing pinkish brown color. The physico-mechanical tests conducted include compressive strength, porosity, water absorption, density and these properties were used to discriminate potential areas at Entoto, Bole Lemi and Meri areas.

\section{GEOLOGICAL SETTING}

Jelenc (1966), Mohr (1967), and later works on geology of Ethiopia (Kazmin, 1979, and later editions) included the geology of Addis Ababa within the context of the Ethiopian Rift Valley. In 1973, Morton summarized the works of Addis Ababa University students and compiled geological map of the city. Kebede Tsehayu, and Taddesse Hailemariyam (1990) produced 1:250,000 scale engineering geological map of the city of Addis Ababa using 1:250,000 scale Landsat image. This was perhaps the first comprehensive map in modern times. Physiographically, the city of Addis Ababa is situated at a south facing slope of the Ethiopian Rift Valley which shows typical volcanic features. The volcanic mountains surrounding the city include Entoto Chain Mountain in the North, Wechecha range in the southwest, and Mount Furi, and further south-East Mount Yerer. There is a general decrease in elevation from north to south direction. The geology of the Addis Ababa city is comprised of rocks ranging from Lower Miocene to Quaternary. The rock units include aphanitic basalt, tuff-agglomerate, trachyte, rhyolite, ignimbrite, trachybasalt, scoracious basalt and alluvium (Fig 2). Thick basalt units underlie younger volcanic rocks on the northern and southern part, 
belonging to the recent volcanism of Wechecha, Furi and Yerer. Scoria cones are abundant especially in the southern and south eastern part of the suburbs of the city.

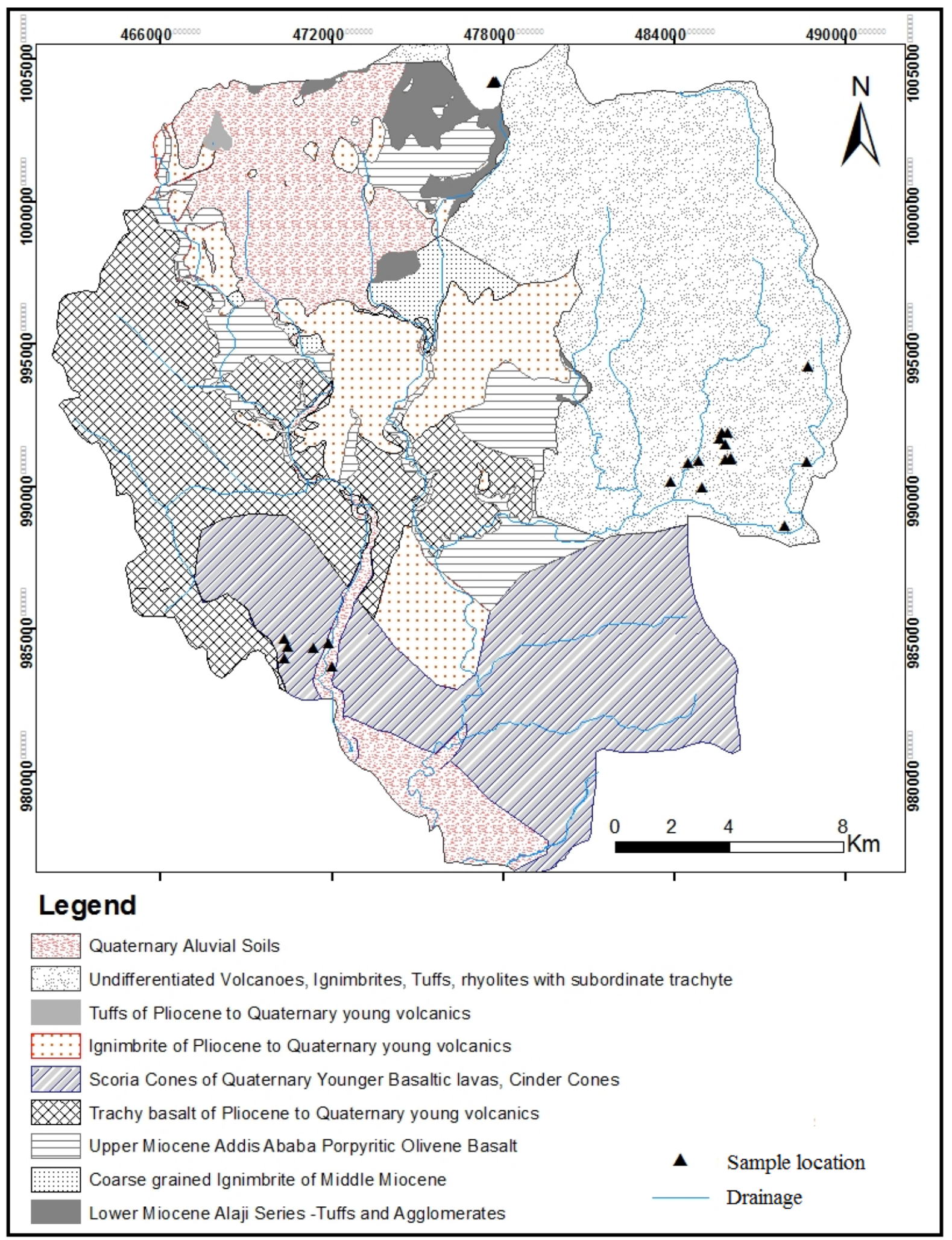

Figure 2. Modified geological map of Addis Ababa city (after SEURECA SPACE \& BCEOM, 1996). 


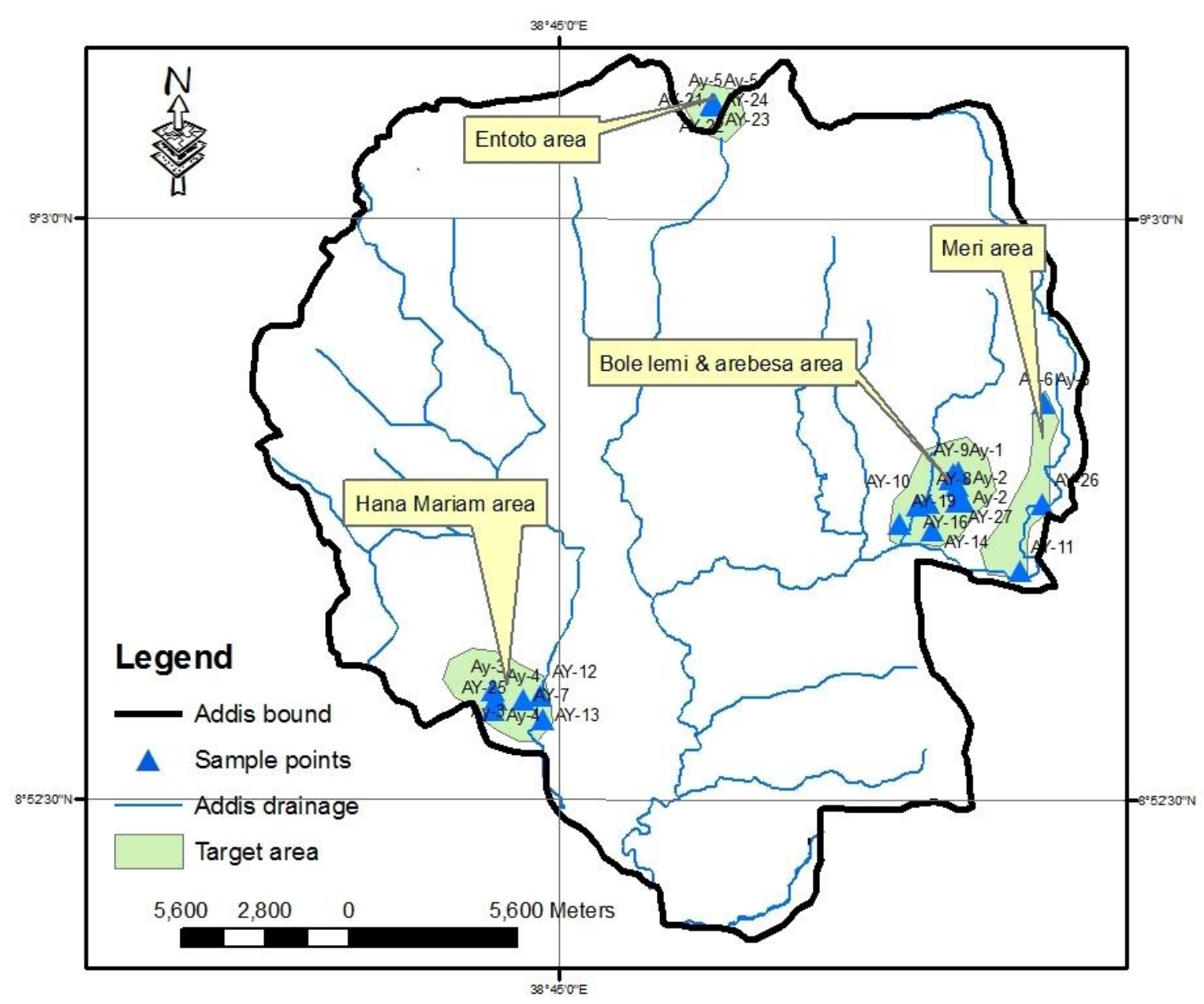

Figure 3. Location map of the target areas and sample locations.

The basalt outcrops are generally compact and spheroidically fissured. Rhyolite forms chain ridge in slopes of Entoto Mountain. Ignimbrite or welded tuff occurs in many places in BoleKotebe, Hana Mariam-Akaki-Kality, Keranyo, and Burayu areas mostly underlain by the tuff unit.

\section{DESCRIPTION OF SELECTED TARGET AREAS}

\subsection{Target Area 1- Bole Lemi}

The area generally shows flat topography with slight tilt sloping northwards. The deposit extends north-easterly and then bends to the west. Access is possible through a dirt road connecting the village from Ayat-Yerer main road. The geology of the area is dominated with acidic volcanic rocks. These include ignimbrite and poorly welded tuff with similar chemical composition. Rock exposure observed in a small quarry opened by local people show that the 
ignimbrite rock unit is fresh, dark gray, medium to coarse grained, joint sets with E-W and N$\mathrm{S}$ trends are also observed with a random non persistent joint set.

\subsection{Target Area 2- Bole Arabesa Area}

The site is accessible through a seasonal dirt road which is motorable by a 4WD vehicle. It is generally flat with very low slope angle facing east. However, after 600 metres the elevation drops significantly to the meandering section Akaki river bed to the east and southeast. The rock constituting bed and flanks of this river which drains the site is basalt. Overlying the basalt is the tuff and weathered basalt followed by ignimbrite (welded tuff). Ignimbrite occurs forming a ridge and continues towards west where the area is cultivated. Normally, in Bole Arabesa area ignimbrite occupies flat topped areas with less significant relief while the tuff unit usually occupies lower topography. A quarry of columnar jointing ignimbrite was active during the field work.

\subsection{Target Area 3-Meri area}

This site is located in Meri Peasant Association, about $2.5 \mathrm{~km}$ south of Ayat Condominium apartments. It is also few hundred meters to the left of Ayat-Yerernew tarmac road. The dominant geology of the area is ignimbrite which covers the flat, large part of farmlands overlying the tuff unit. The tuff unit occurs in sloppy areas and subdued topographies, where at places form small cliffs as a result of intermediate compaction. The rock in this area is most preferred for wall cladding and other decorative purposes and is under exploitation as observed during the field excursion. The unit has intermediate compaction perhaps less than ignimbrite and more than ordinary tuff.

\subsection{Target 4-Hana Mariam Area}

The potential site for ignimbrite in south western Addis Ababa is located in Hana-Erto-Lebu, Nefas-Silk-Lafto sub-city areas. The deposit is accessible through a motorable dirt road using 4WD vehicle. Basalt outcrop was also observed in the upper section of the small valley near developed Municipal water well. The basalt shows extreme fracturing and bending evidencing late deformation. Remarkably, the area west of the small valley (i.e. left side of the perennial stream) is covered with basalt which continues upwards to the main mountainous topography. The right side of the valley and its mapped floor is ignimbrite of various colours at outcrop scale of observation.

\subsection{Target 5-Kality Area}

Access is possible through all-weather gravel road which is in frequent use by a number of crushed stone producing companies. Basalt with columnar joints and extensive exposure 
(cliff forming at places) forms the bed rock geology in the area. It is scoraceous at the upper sections. Tuff unit overlies the scoraceous basalt in some sections. Generally, ignimbrite overlies the basalt unit in most places which also shows columnar jointing. Ignimbrite outcrop continues northwards for more than $100 \mathrm{~m}$ along the margin of the small River. The rock shows similar characteristics, and joint sets of E-W, N-S and a third horizontal or flat joint.

\subsection{Target 6- Entoto Rhyolite}

The rhyolite mountain is part of Entoto silicic formation which is located underneath Entoto Mountain range at an elevation of about $2835 \mathrm{~m}$ above mean sea level. The geology of the middle section of the ridge is basalt. Thin section studies of sample Ay-5 confirmed that the reddish brown to light brown lithic rhyolite is coarse grained and contains rock fragments $(50 \%)$, quartz (25\%), sanidine (20\%), and opaque (5\%). The ground mass of the rock is composed of mostly pumice. The petrographic description also indicates that the voids of the rock are unfilled perhaps due to secreting gaseous material during rock formation (volcanic eruption and solidification).

\subsection{Target Area 7-Kotebe Area}

It is accessible through all weathered gravel road from the main asphalt northwards direction. The rock mass is fractured, jointed and is about 5-6 m thick, light gray to gray coloured, fine grained and slightly weathered on the surface as observed in an abandoned quarry. The diameter of the deposit is about $90 \mathrm{~m}$ from E-W and about $70 \mathrm{~m} \mathrm{N-S}$. No sample is taken for either petrographic study or technological test as settlements area already advancing behind the quarry. It is a fine grained trachyte with reddish tint.

\section{RESULTS AND DISCUSSION}

\subsection{Need for quality assessment of dimension stone}

The field and laboratory works carried out during present research study were compiled and compared together to reveal the engineering performance of the rock mass in terms of construction material suitability. Volcanic rock shows a variety of textural and mineralogical characteristics which could affect their physical and mechanical properties as well as their use as construction material. The physical properties especially water absorption is found to be a useful property in assessing durability of various rocks used as dimension stone. In assessing of a rock for use as a dimension stone, the first requirement is petrographic study to identify its mineralogy, grain size, textures, fabrics and weathering states. 
All these processes are in turn determined by the geological processes which formed the rock. A good understanding of these processes and effects will enable to determine a rock's suitability as construction materials. For precise description of the rocks, two thin sections from the most abundant rocks of the study area were prepared and studied under polarizing microscope. Even though, the aim of this examination is the classification of the natural stone, also observations of features that influence its chemical, physical and mechanical behavior are carried out. Generally, the petrographic examination of rocks used for dimension stone and aggregate are crudely categorized into three steps, a) classification, b) an aid in the assessment of aggregate performance, c) detection of potentially deleterious constituents. Each thin section is described in detail (Table 3). However, the volcanic rocks classified with modal value (microscopic) as ignimbrite and rhyolite can have substantial variations in chemical compositions.

Geological construction materials form the major part of all construction materials used in civil engineering projects. Despite their low unit value these 'geomaterials' are of prime economic importance because of huge tonnages used each year. Like all construction materials, geomaterials must comply with certain specifications for an application. These specifications concern the physical, chemical and mechanical durability characteristics. By meeting these durability specifications, the geomaterials should maintain their physical, mechanical and chemical integrity throughout the life time of the construction in which they are applied. Because of the compositional variability of geo-materials, which is inherent to their natural origin, the assessment of their durability properties is not obvious. Many attempts have been made to relate the durability characteristics measured in the laboratory to their behaviour in engineering structures, often without much success. Majority of the rocks near the earth's surface are affected by natural weathering processes. In every rock, even if classified as 'fresh', minor amounts of secondary minerals may be present. Their presence can have detrimental effects and lead to accelerated degradation when the material is 'inservice' in the engineering structure.

The standard definition of durability given in American Society of Testing and Materials (ASTM) is the measure of the ability of natural building stone to endure and maintain its essential and distinctive characteristics such as strength, resistance to decay and appearance, with relation to a specific manner, purpose, and environment of use. With respect to geological construction materials this is usually explained as the ability of a material to keep its mechanical and physico-chemical characteristics throughout its engineering lifetime, 
under the influence of the engineering environment and in relation to the intended usage. Even if, mechanical and physical laboratory tests indicate that a geomaterial has suitable properties for the engineering structure considered, the presence of weathering minerals or unfavourable microtexture could be problematic. The durability of geomaterials is related to their intended use and function; durability is only required in relation to those properties that are relevant for the functionality of the engineering structure. It should be noted that durability is not an overall constant. It relates to different properties in a variety of ways.

Table 1. Showing comparison of different countries standards.

\begin{tabular}{|l|l|c|c|}
\hline \multirow{2}{*}{ Test type } & \multicolumn{2}{|c|}{ Standards } & \multirow{2}{*}{ Other Standards } \\
\cline { 2 - 4 } & $\begin{array}{c}\text { British } \\
(\text { BS })\end{array}$ & $\begin{array}{l}\text { American } \\
(\text { ASTM })\end{array}$ & \\
\hline Petrography & $\checkmark$ & $\mathrm{x}$ & $\checkmark$ (Italian) \\
\hline Bulk density & $\checkmark$ & $\checkmark$ & - \\
\hline Water absorption & $\checkmark$ & $\checkmark$ & $\checkmark$ (French) \\
\hline Porosity & $\checkmark$ & $\mathrm{x}$ & $\checkmark$ (Italian) \\
\hline Chemical analysis & $\checkmark$ & $\checkmark$ & - \\
\hline Uniaxial compressive strength & $\checkmark$ & $\checkmark$ & (French \& German) \\
\hline
\end{tabular}

In summary, the durability of geomaterials should be considered in relation to the engineering environment to which they are exposed, the expected, life time of the engineering structure and the function they have to perform in this structure. Current practice in construction requires that material testing is performed as much as possible, using the test methods described in official standards (e.g. ISO, BS, UNIEN and ASTM). Rock durability tests include density, water absorption, uniaxial compressive strength and porosity etc.

However, density and water absorption have been found to be useful indicators of material quality. Water absorption is the single most important indicator of resistance against degradation and also a good indicator of weathering resistance. In fact, it is clear that a single test is not sufficient to indicate suitability. Evaluation of several test results, determining the physical, chemical and mechanical durability characteristics is necessary. One should also be sure that no unknown defects are present in the rock. Important in this respect are the presence of detrimental minerals and structures.

Deposits of dimension stone are subjected to much greater selectivity with respect to physical properties, uniformity, and modes of occurrence; these demand a much more critical and detailed study of geologic and mineralogic features (Currier, 1961). 
Coarse textured rocks are generally more durable than fine textured materials. Stone with high proportion of very fine pores tends to be less durable than stones with a coarser pore size distribution. Petrographic examination of the rock can give extremely valuable information on mineralogy and micro porosity. It is recommended that all studies of dimension stones should include the preparation and examination of thin sections.

This study focuses primarily on dimension stone which in addition to the above technological requirements, requires a knowledge or familiarity of international dimension stone trends (i.e. what stone types to focus efforts on) and basic geological factors which dictate weather a stone can be quarried. A wide range of rock materials can be used as dimension stones and includes various types of volcanic, sedimentary and few metamorphic rocks provided that it can be cut and dressed into regular shapes or sizes for use in construction. The currently assessed project area is volcanic as it is situated within Addis Ababa and surroundings.

Dimension stone is used primarily in the building and construction industry, in urban landscaping industries, and in tombstones, monuments and ornamental objects, and numerous other applications. Thus, in addition to the physico-mechanical properties of a particular dimension stone which are of prime importance, it is the visual or aesthetic appearance and prestige of the stone that drives the stones marketability for both residential and commercial usage. Irrespective of the geological provenance, the selection of use depends on the durability, aesthetic qualities and associated factors. However, the evaluation of stone is only reliable if the samples available for inspection and testing are representative. This is partly governed by the scale of observation and the level of detail of the geological investigation. Although, natural stone is a variable product it is important that variability is kept within limits which are known and understood.

In this regard, during the course of this study, representative sampling was carried out from the exposed fresh part of the deposits. The collected samples were subjected to laboratory analysis which includes bulk density, porosity, water absorption, uniaxial compressive strength tests. Besides, petrographical examination was conducted on selected representative samples. The physical tests and other tests were conducted in the central laboratory of Geological Survey of Ethiopia at Addis Ababa which has a good reputation in such tests.

\subsection{Interpretation of laboratory results}

The lists of selected tests for the current study were: a) porosity; b) bulk density c) water absorption; d) compression strength. The samples utilized for conducting these tests, however, remained confined to the specific target areas. The results helped to identify the 
rock at Entoto as rhyolite while that of Hana Mariam indicated minerals which potentially provide greenish tint and yellowish colour in addition to other anticipated coloration. The results of the 24 samples collected from four different sites which were subjected to physicomechanical tests at Ethiopian Geological Survey Central Laboratory (CGSE) are listed in Table 2 below. Similarly, petrographic studies on two samples are displayed in table 3 . These results are interpreted based on the British standard (BS: 812: part 2(1975) and ISRM: 1981 (International society for rock mechanics) for dimension stone.

Table 2. Summary of major physical tests results.

\begin{tabular}{|c|c|c|c|c|c|}
\hline \multirow[t]{2}{*}{ S No } & \multicolumn{4}{|c|}{ Tests conducted } & \multirow[t]{2}{*}{ Remark } \\
\hline & $\begin{array}{l}\text { Porosity } \\
(\%)\end{array}$ & $\begin{array}{c}\text { Bulk } \\
\text { density } \\
(\mathrm{g} / \mathrm{cm} 3)\end{array}$ & $\begin{array}{c}\text { Water } \\
\text { absorption } \\
\%\end{array}$ & $\begin{array}{c}\text { Unconfined } \\
\text { compressive } \\
\text { strength } \\
(N / m m 2) \\
\end{array}$ & \\
\hline \multicolumn{6}{|c|}{ Bole Lemi \& Arebasa area $($ Target1\&2) } \\
\hline AY-1 & 15.5 & 2.21 & 7.07 & 127.8 & Ignimbrite \\
\hline Ay-2 & 23.27 & 1.86 & 12.47 & 32.13 & Ignimbrite, with yellowish tint \\
\hline AY-8 & 4.54 & 2.71 & 1.68 & 123.56 & Rhyolitic tuff/ignimbrite \\
\hline AY-9 & 8.79 & 2.73 & 3.22 & 78.34 & Rhyolitic tuff/ignimbrite \\
\hline AY-10 & 6.14 & 2.77 & 2.22 & 57.8 & Rhyolitic tuff/ignimbrite \\
\hline AY-14 & 6.56 & 2.45 & 2.67 & 88.36 & Ignimbrite \\
\hline AY-15 & 3.98 & 2.83 & 1.4 & 67.23 & Ignimbrite \\
\hline AY-16 & 10.74 & 2.54 & 4.23 & 70.54 & Ignimbrite \\
\hline AY-17 & 16.85 & 2.21 & 7.61 & 45.31 & Rhyolitic tuff \\
\hline AY-18 & 6.6 & 2.75 & 2.4 & 52.27 & ignimbrite \\
\hline AY-19 & 2.12 & 2.91 & 0.73 & 78.55 & ignimbrite \\
\hline AY-27 & 4.27 & 2.7 & 1.58 & 147 & ignimbrite \\
\hline \multicolumn{6}{|c|}{ Meriarea (Target3) } \\
\hline Ay-6 & 16.16 & 2.19 & 7.41 & 118.1 & Ignimbrite \\
\hline AY-11 & 1.37 & 2.84 & 0.49 & 145.37 & Ignimbrite \\
\hline \multicolumn{6}{|c|}{ Hanna Mariam area(Target 4) } \\
\hline Ay-3 & 20.82 & 2.08 & 10.23 & 28.36 & Ignimbrite with greenish spot \\
\hline Ay-4 & 24.72 & 1.97 & 12.61 & 25.22 & Ignimbrite \\
\hline AY-7 & 17.19 & 2.17 & 7.92 & 98.79 & Ignimbrite slightly weathered \\
\hline AY-12 & 15.03 & 2.2 & 6.81 & 127.1 & Tuff, welded \\
\hline AY-13 & 12.78 & 2.28 & 5.61 & 93.40 & Ignimbrite \\
\hline AY-25 & 19.73 & 2.11 & 9.33 & 25 & Welded tuff/ignimbrite \\
\hline \multicolumn{6}{|c|}{ Entoto area (Target6) } \\
\hline Ay-5 & 8.41 & 2.41 & 3.33 & 59.00 & rhyolite \\
\hline AY-21 & 6.9 & 2.38 & 2.89 & 56.31 & rhyolite \\
\hline AY-22 & 4.46 & 2.72 & 2.01 & 74 & rhyolite \\
\hline AY-23 & 4.48 & 2.81 & 1.6 & 87 & rhyolite \\
\hline AY-24 & 5.62 & 2.5 & 2.24 & 85 & rhyolite \\
\hline
\end{tabular}


Table 3. Petrographic result for two major rock types.

\begin{tabular}{|c|c|c|c|c|c|c|c|}
\hline \multirow[t]{2}{*}{ S.No } & \multicolumn{7}{|c|}{ Mineral composition by mass volume } \\
\hline & $\begin{array}{l}\text { Vitric } \\
\text { glass } \\
(\%)\end{array}$ & $\begin{array}{c}\text { Rock } \\
\text { Fragments } \\
(\%)\end{array}$ & $\begin{array}{l}\text { Chalcedony } \\
\text { quartz }\end{array}$ & $\begin{array}{l}\text { Devitrified Pyroxene } \\
\text { glass }\end{array}$ & sanidine & opaque & Rock name \\
\hline AY-3 & 40 & 25 & 6 & 5 & 20 & 1 & Ignimbrite \\
\hline Ay-5 & - & 50 & 25 & - & 20 & - & Lithic rhyolite \\
\hline
\end{tabular}

In order to develop relationships between water absorption, unconfined compression strength (UCS), porosity, and bulk density simple regression analyses were used. Regression analysis is normally used to create a mathematical model that can be used to predict the values of a dependent variable based upon the values of an independent variable. To perform the regression analyses, the results indicated on table 2 were plotted in 2-dimensions as a scatter plot. This format allows visualization/inspection of the data prior to running a regression analysis. Different curve fitting relationships, such as linear, exponential, logarithmic, polynomial, and power, can be used to analyse the relationship between a dependent and independent variable. The curve fitting relationships produce a coefficient of determination $\left(\mathrm{R}^{2}\right)$. The coefficient of determination is the measure of the proportion of variability on one variable that can be accounted for variability on the other variable. Once all possible regression curves fits and associated $\mathrm{R}^{2}$ values have been determined, typically the most appropriate is the curve fit is the one with the highest $\mathrm{R}^{2}$ value.

Based on the literature review, linear relationships are expected between bulk density and porosity, water absorption and porosity. Also a linear or exponential relationship is expected between the unconfined compressive strength (UCS) and point load strength, however unfortunately we could not carried on point load test.

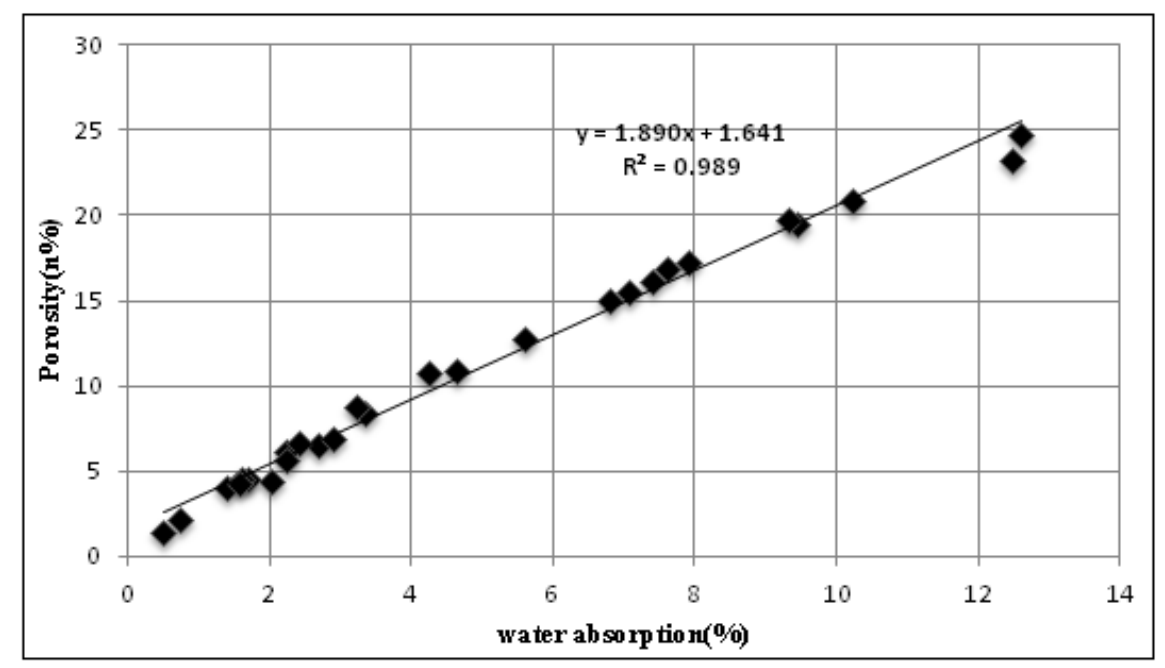

Figure 4. Linear relationship between porosity and water absorption of all the ignimbrite and rhyolitic tuff volcanic rocks. 


\subsubsection{Porosity and water absorption}

The results of porosity and water absorption were plotted in a 2 dimension scatter plot and regression analysis was carried on. Figure 4 presents the relationship between porosity and water absorption. The linear relation is good with $\mathrm{R}^{2}=0.989$, however there is a bit scatters points at lower and higher values.

\subsubsection{Bulk density as a function of porosity}

The relationship between bulk density and porosity is linear as shown in figure 5 .

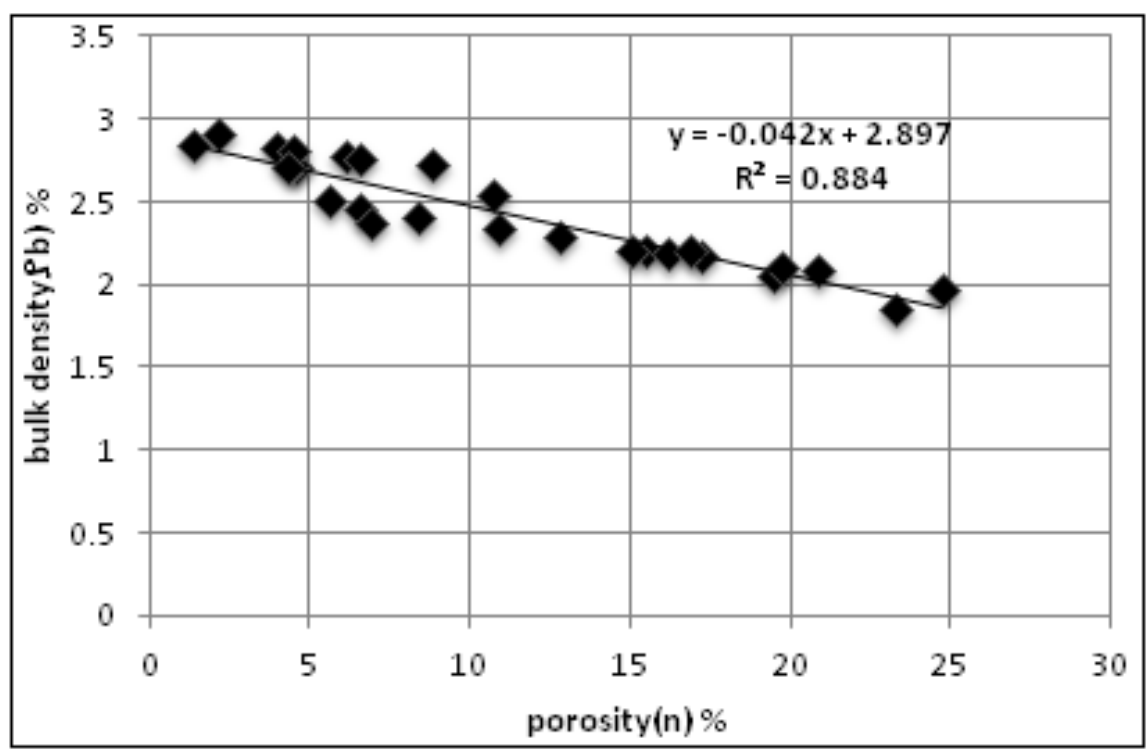

Figure 5. Graph showing Porosity versus bulk density.

\subsubsection{Bulk density as a function of water absorption}

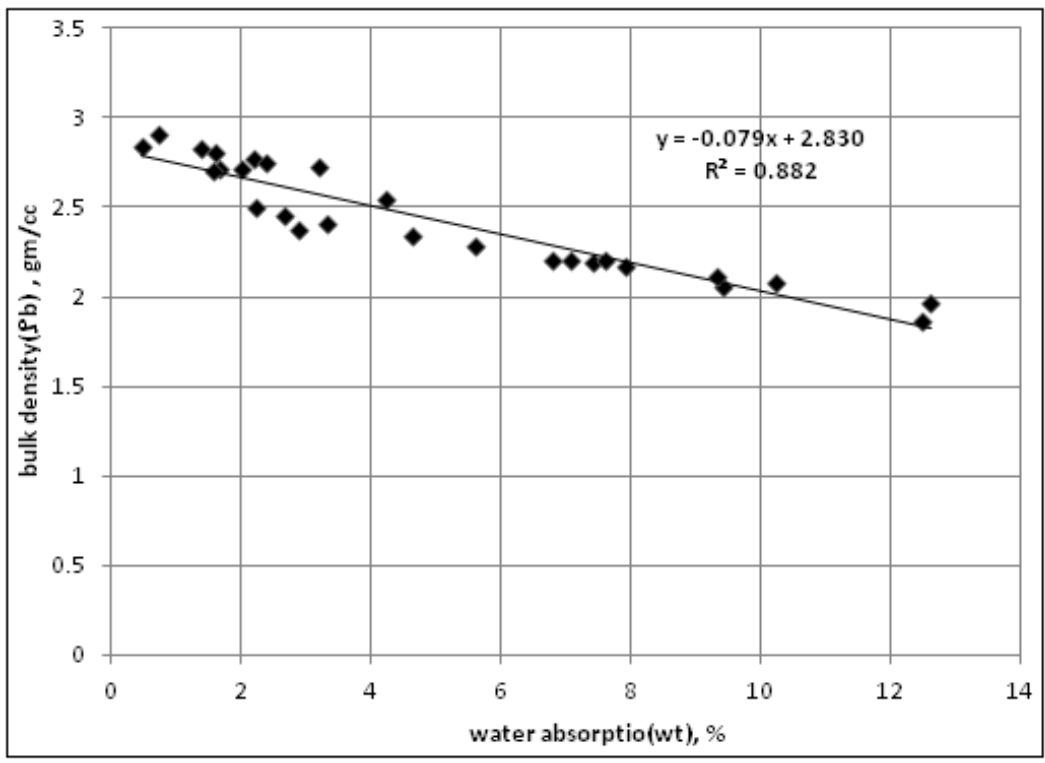

Figure 6. Water absorption versus bulk density. 


\subsubsection{Compression strength as a function of porosity and water absorption}

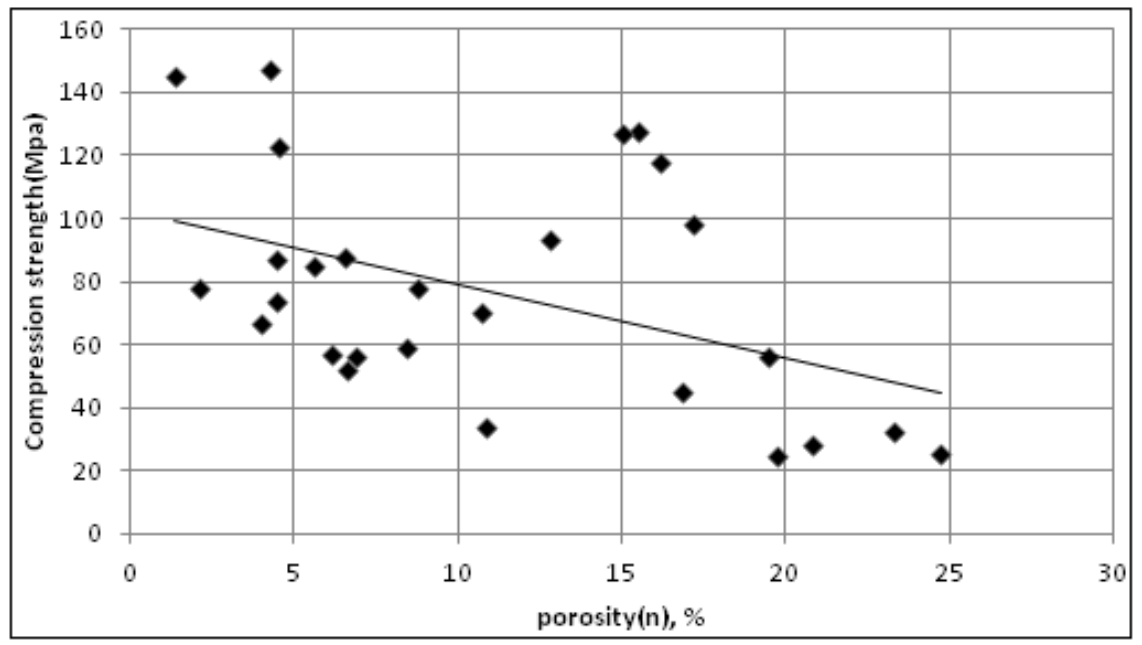

Figure 7. Compression strength as a function of total porosity.

There is no such clear relation between the two rock properties however there is a general trend that with increasing porosity, decreasing compression strength. Also the relation between compression strength and water absorption is the same to the above graph so it is difficult to derive a clear relation. However, Kossev (1970); and Smorodinov et al. (1970) studied separately the relationship between porosity and compressive strength on carbonate rocks (limestone and dolomite), quartzites and quartzites-sandstones and magmatic rocks. The higher the porosity the lower the strength and both relations were exponential with a correlation factor of around 0.8 . The same authors demonstrated the positive relation between strength and apparent density, i.e. an increase in the compressive strength shows an increasing apparent density. Generally, the best fit regression line is plotted for the porosity vs. water absorption and porosity versus bulk density; the $\mathrm{R}^{2}$ value $(0.98)$ is high. As seen in the figure 4 , the points are plotted on or near the best fit line; therefore, the $\mathrm{R}^{2}$ value for these relations are very reliable.

\subsection{Discussion on the selected target areas}

\subsubsection{Bole Lemi \& Arabesa area (target area 1\&2)}

12 samples were taken from this target area, which is located on the south eastern surroundings of Addis Ababa. The samples show good greyish colour with occasional faint greenish grey tint. The laboratory results of these samples show good results of strength, water absorption, bulk density and Porosity except two samples. So, over $90 \%$ of the samples meet the specification of BS: 812 , to be used as pavements, ashlars, cobble stone, rubble and 
fencing. The relatively higher value of the porosity inhibits these materials to be used as armourstone and generally as corridor pavements where there is frequent water contact. Otherwise it can be used as cladding masonry ceiling and for different internal decorations. The compression strength varies from $32-127 \mathrm{MPa}$ which make also these samples preferable for structural loading.

\subsubsection{Meri Area (target area 3)}

Two samples were collected from an extensive quarry of Meri area. The samples showed very high compressive strength (118-145MPa) and relatively good water absorption and bulk density. But the high porosity value makes its use limited. The excellent compressive strength warrants to be used as structural loading, where there is no direct contact to ground water or rain water. Currently, the quarry owners are producing huge amounts of rough quarry blocks for fencing and paving. However, the study team recommends that as these samples display relatively high porosity and water absorption, protective stucco/water proof could be used to protect the rock from direct exposure to rain, daily fluctuation of relative humidity and urban weathering. The rock should not also be used as armourstone where there is direct water contact or water lodged underground foundation.

\subsubsection{Hanna Mariam area (target area 4)}

Six greenish grey ignimbrite samples were collected from active quarry sites in Hana Mariam area. Despite its excellent appearance the samples showed relatively low strength and high porosity which makes it vulnerable to degradation/weathering. So, these samples could not be used as corridor pavement and masonry but to a certain extent it could be used as cladding stone cutting in smaller pieces for internal use. The bulk density and water absorption is still above the acceptable limit. Therefore, in view of these discouraging results the use of this site as dimension stone source is unlikely or impossible with respect to the current tight specifications; however, for domestic use it could serve as interior decorative stone where there is no frequent water contact and abrasion.

\subsubsection{Entoto area (target area 6)}

This target area is located on the northern outskirt of Addis Ababa city and five samples were collected and studied. The compression strength varies from 56-85MPa with excellent porosity and water absorption properties. Therefore the area could be further studied and used for dimension stone quarry. Microscopic study of the rock identified the unit as lithic ryholite with quartz and sanidine phenocrysts in a fine grained groundmass. 
Thus, for the reasons mentioned above only two sites are selected as development areas: Bole Lemi-Bole Arabesa and Entoto Rhyolite.

\section{CONCLUSIONS}

The study conducted in the surrounding area of Addis Ababa city provided two prospective sites for quarrying geological construction materials (dimension stones for various applications) in the Entoto rhyolite and Bole Lemi and Arabesa ignimbrites. The Entoto rhyolite was found to be the best of all the studied rocks in terms of physico-mechanical tests. The rhyolite samples from Entoto showed low porosity, high bulk density, good comprehensive strength and very low water absorption which make the rock suitable to be used as dimension stone.

Bole Lemi and Bole Arabesa ignimbrites have been tested to be good for various applications except armourstone and generally as corridor pavements where there is frequent water contact. Otherwise it could be used as cladding masonry ceiling and for different decorations. This sample show excellent strength and density which makes it preferable for structural loading where there is no direct water contact. Ignimbrites at Meri also show relatively good result but are found to have high porosity. In this contribution, we tried to present prospects for using the variety of volcanic rocks in and around Addis Ababa city for the production of dimension stone, to be used for pavement tiles, monuments, exterior building components and others.

\section{ACKNOWLEDGEMENTS}

This research work is funded by Geomatrix plc for field logistics support and for the laboratory analysis. I would like to extend my thanks to Ethiopian Geological Survey and the Ethiopian Transport Construction and Design Enterprise for the laboratory work. I would like to appreciate and thank the reviewers for their critical comments for the improvement of the quality of the paper.

\section{REFERENCE}

Abera, S. 1994. Review of Industrial Minerals of Ethiopia. AGID Report Series, Geoscience in International Development, 18:173-180.

Barton, N \& Choubey, V. 1977.The shear strength of rock joints in theory and practice. Rock mechanics and rock engineering. J. Eng. Geol., 10 (1-2): 1-54. 
Collis, I \& Fox, R. A.1985. Aggregates: Sand, Gravel and Crushed Rock Aggregates for Construction Purposes. Geological Society of London, Engineering Geology Special Publication No. 1, the Universities Press Ltd (Belfast), London.

Christaras, B. 1996. Non-destructive methods for investigation of some mechanical properties of natural stones in the protection of monuments. Bull. Int. Assoc. Eng. Geol., 54: 59-63.

Currier, L.W. 1960. Geologic appraisal of dimension stone deposits. USGS Bulletin, 1109, Washington, D.C., 78p.

Engidasew, Tesfaye Asresahagne \& Barbieri, G. 2014. Geo-engineering evaluation of Termaber basalt rock mass for crushed stone aggregate and building stone from Central Ethiopia, University of Cagliari, Journal of African Earth Sciences, 99: 581594, http://dx.doi.org/10.1016/j.jafrearsci.2013.11.020

Fookes, P.G. 1980. An introduction to the influence of natural aggregates on theperformance and durability of concrete. Quart. J. Engineering Geology, 123(4):207-229.

Ghebre, W.M. 1991. Construction raw materials in Ethiopia: a summary from previous works. EIGS, Mineral Exploration Department, Internal report (unpubl.).

Goodman, R.E. 1992. Engineering Geology: Rock in Engineering Construction. Wiley, New York, Second ed. Wiley, New York, 562p.

Hudson, J.A \& S.D. Priest. 1979. Discontinuities and rock mass geometry. Int. J. Rock Mech. Min. Sci. Geotech. Abs., 16: 339-362.

Hofmann, C., Courtillot, V., Feraud, G., Rochette, P., Yirgu, G., Ketefo, E \& Pik, R. 1997. Timing of the Ethiopian flood basalt event and implications of plume birth an global change. Nature, 389: 838-841 (http://dx.doi.org/10.1038/39853).

Jelence, D. 1966. Mineral Occurrences of Ethiopia. Report, Ministry of Mines, Addis Ababa, Ethiopia (unpubl.).

Karstaedt \& Wondafrash, M. 1986a. Geological construction material around Bole area, Addis Ababa. Report, Institute of Geological Survey of Ethiopia, Addis Ababa (unpubl.).

Karstaedt, H \& Wondafrash, M. 1986b. Summarized Report on Building Raw Material in Eastern Addis Ababa (Bole). Report, Ethiopian Institute of Geological Surveys, Addis Ababa (unpubl.).

Kazmin, V. 1979. Stratigraphy and Correlation of Cenozoic Volcanic Rocks in Ethiopia. Report, Ethiopian Institute of Geological Survey, Addis Ababa, 106:1-26. 
Kebede Tsehayu, and Taddesse Hailemariyam. 1990. Engineering geology mapping of Addis Ababa. Report, Ethiopian Institute geological survey, Addis Ababa (unpubl.).

Kossev N.V. 1970. Correlation between the physical and mechanical properties of rocks and degree of their weathering, Proceedings of the Second Congress of the International Society for Rocks Mechanics, Beograd, pp.29-35.

Mengistu, T \& Fentaw, H.M. 2000. The industrial mineral and rock resource potential of Ethiopia. Chron. Rech. Min., 540: 33-40.

Mengesha, T., Tadiwos, C \& Workineh, H. 1996. Geological Map of Ethiopia; 1:2,000,000. Ethiopian Institute of Geological Surveys, Addis Ababa.

Merke, G. 2000. Sustainable development in the natural stone industry. Roc Maquina, pp.5658.

Mohr, P. 1967. Transcurrent faulting in the Ethiopian rift system. Nature, 218: 938-941.

Morton W.H. 1979. Rift wardyounging of volcanic units in Addis Ababa region, Ethiopia.

Mulugeta H., Asegid, G \& Kifle Mariam, G. 2007. Geological Map of Addis Ababa City, Geological Survey of Ethiopia, Addis Ababa.

Neville, A.M. 1995. Properties of Concrete. Fourth ed. Pitman, London, 844p.

Pik, R., Deniel, C., Coulon, C., Yirgu, G., Hoffmann, C \& Ayalew, D. 1998. The northwestern Ethiopian Plateau flood basalts: classification and spatial distribution of magma types. J. Volcanology Geothermal Resources, 81: 91-111.

Ramsay, D.M., Dhir, R.K \& Spence, I.M. 1974. The role of rock and clast fabric in the physical performance of crushed-rock aggregate. Eng. Geol., 8:267-285.

SEURECA SPACE \& BCEOM, 1996: Groundwater potential study and design for Addis Ababa city. Report, Addis Ababa, Ethiopia (unpubl.).

Shadmon, A. 1996. Stone - an Introduction. Intermediate Technology Publication, London.

Sayed Ahmed, M.I., Fayed, L \& Ibrahim, H. 1999. Geotechnical properties of some limestones of the Nile Valley, Egypt. Kuwait J. Sci. Eng., 26 (1):181-195.

Smith, M.R \& Collis, L. 2001. Aggregates: Sand, Gravel and Crushed Rock Aggregates for Construction Purposes. Geological Society, Engineering Geology Special, Publication, 17:339.

Smorodinov, M. I., Motovilov, E. A \& Volkov, V. A. 1970. Determination of Correlation Relationships between Strength and Some Physical Characteristics of Rock. $2^{\text {nd }}$ International Conference on Rock Mechanics, 2: 35-57. 
Tasong,W.S., Lynsdale, C.J \& Cripps, J.C. 1998. Aggregate-cement paste interface: II. Influence of aggregate physical properties. Cem. Concr. Res., 28(10):1453-1465.

Walle, H. 1996. Major dimension stone potential of Ethiopia. Report, Ethiopian Institute of Geological Survey, Addis Ababa, 13p (unpubl.).

Walter, L \& Werner, G. 2003. Manual on the Geological-technical Assessment of Mineral Construction Materials, Germany, 448p.

Wondafresh, M., Haileyesus, W \& Hailu, B. 1993. Limestone and gypsum resources at Wonchit and Jema Area Merhabete Northern Shoa. Report, Ethiopian Institute of Geological Surveys, Addis Ababa (unpubl.).

Zanettin, B \& Justine-Visentin, E. 1974. The Volcanic Succession in central Ethiopia 2. The Volcanics of the Western Afar and Ethiopian rift margins, Mem. 1st Geol. Miner. Univ. Padova, 31:19. 